\title{
Pelatihan Penggunaan Aplikasi GUI Matlab untuk Materi Dinamika Gerak
}

\author{
Yulia Fitri*, Delovita Ginting, Shabri Putra Wirman, Neneng Fitrya, \\ Sri Fitria Retnawaty, Noni Febriani \\ Program Studi Fisika, Fakultas MIPA dan Kesehatan, \\ Universitas Muhammadiyah Riau \\ email: yuliafitri@umri.ac.id
}

\begin{abstract}
The dynamics of motion is a branch of science that studies motion and its causes. One of the difficulties of students to understanding the dynamics of motion is students cannot describe the forces in the system. To help students understand it, the material is delivered using an attractive, interactive and comprehensive application, namely using the Matlab GUI. In addition, this service aims to develop skills or approaches for teachers and create alternative learning media, especially the dynamics of motion. The methods used are training and mentoring. The training is the use of the GUI Matlab application, assistance is also carried out related to improving the ability of teachers to explore, elaborate and reflect on the dynamics of motion and improve teacher skills in implementing the learning designs that are made as well as improving learning designs. The results of this training showed that participants excited following the training was, they feel more easier to understand the dynamics of the motion of material with many variations questions.
\end{abstract}

Keywords: Dynamics Motion, Newton Law, GUI application, MATLAB

\begin{abstract}
Abstrak
Dinamika gerak merupakan cabang ilmu yang mempelajari tentang gerak beserta penyebabnya. Salah satu kendala siswa dalam memahami dinamika gerak adalah siswa tidak bisa menguraikan gaya-gaya yang bekerja pada system tersebut. Untuk membantu siswa memahaminya, maka materi disampaikan menggunakan aplikasi yang menarik, interaktif dan komprehensif yaitu menggunakan GUI Matlab. Selain itu, pengabdian ini bertujuan untuk mengembangkan keterampilan atau pendekatan bagi guru serta menciptakan alternatif media pembelajaran khususnya materi dinamika gerak. Metode yang dilakukan adalah pelatihan dan pendampingan. Pelatihan yang dilakukan adalah pelatihan penggunaan aplikasi GUI Matlab. Pendampingan juga dilakukan terkait dengan meningkatkan kemampuan guru dalam mengeksplorasi, mengelaborasi dan merefleksi materi dinamika gerak serta meningkatkan keterampilan guru dalam mengimplementasikan rancangan pembelajaran yang dibuat sekaligus penyempurnaan rancangan pembelajaran. Hasil evaluasi pengabdian ini menunjukkan bahwa peserta senang bisa mengikuti kegiatan pelatihan ini, lebih mudah memahami materi dinamika gerak dengan banyak variasi soal-soal.
\end{abstract}

Kata Kunci : Dinamika gerak, hukum newton, gui, matlab

\section{PENDAHULUAN}

Seiring dengan kemajuan sistem Teknologi Informasi (TI), salah satu hal yang perlu dilakukan guru adalah mengembangkan sistem pendidikan dengan menciptakan media, metode dan materi pendidikan yang semakin menarik, interaktif dan komprehensif [1]. Peran media simulasi dalam pembelajaran sebagai alat bantu untuk memberikan perangsangan pada siswa sehingga dapat menghidupkan suasana belajar siswa, membantu siswa dalam memahami pembelajaran [2]. Hal ini didukung dengan 
Undang-Undang Republik Indonesia Nomor 20 Tahun 2003 Pasal 36 bahwa kurikulum untuk semua jenjang dan jenis pendidikan harus memperhatikan perkembangan ilmu pengetahuan dan teknologi.

Matlab (Matrix Laboratory) merupakan software aplikasi interaktif untuk komputasi numerik dan visualisasi data. Matlab merupakan bahasa pemrograman level tinggi sehingga sangat mudah untuk dioperasikan. Matlab banyak digunakan oleh kalangan akademisi maupun industri. Matlab memiliki fasilitas pengembangan berupa GUI (Graphic User Interface). GUI Designer mengandung menu, tombol, teks, grafik, dan lain-lain dimana pengguna dapat mengubahnya secara interaktif dengan menggunakan mouse dan keyboard [3].

Penggunaan media simulasi dengan GUI Matlab ini, maka guru tidak harus menjelaskan materi pelajaran secara berulang-ulang. Guru lebih fokus pada pengembangan dan pendalaman materi, karena selama ini sebagian potensi guru tercurahkan kepada penyajian materi belajar di depan kelas secara konvensional [4].

Benda di alam bergerak, diam dan sebagainya tidak terjadi secaratiba-tiba. Ada penyebab sehingga gerak tersebut terjadi dan proses gerakpun tidak terjadi secara bebas. Benda selalu bergerak mengikuti aturan yang sudah pasti. Benda yang dilepas dari ketinggian tertentu pasti bergerak jatuh kalau tidak ada dorongan lain yang membelokkan arah gerak. Benda yang dilempar dalam arah horizontal selalu berberak melengkung ke bawah. Paku yang didekatkan ke magnet akan ditarik ke arah magnet. Bumi selalu bergerak mengelilingi matahari pada orbit yang sudah tertentu. Dengan kata lain gerak benda umumnya bersifat determinsitik, artinya dapat diramalkan di mana lintasan yang akan diambil, ke mana arah kecepatan pada tiap titik di lintasan tersebut, dan berapa percepatan tiap saat.
Newton merumuskan hukum-hukum gerak yang sangat luar biasa. Newton menemukan bahwa semua persoalah gerak di alam semesta dapat diterangkan dengan hanya tiga hukum yang sederhana [5].

Persoalan dinamika dan kinematika gerak umumnya merupakan gerbang awal dari persoalan fisika yang dipelajari di sekolah. Hal ini dikarenakan banyak siswa yang kurang mampu menjabarkan penguraian gaya-gaya yang terjadi pada suatu sistem tersebut.

Program Studi Fisika, Fakultas MIPA dan Kesehatan Universitas Muhammadiyah melaksanakan pengabdian kepada masyarakat dalam bentuk kegiatan "Pelatihan Penggunaan Aplikasi GUI Matlab Untuk Materi Dinamika Gerak" untuk Guru-Guru Fisika di SMA 2 Pekanbaru. Pelatihan ini bertujuan mengembangkan keterampilan baru atau pendekatan baru bagi guru serta menciptakan alternatif media pembelajaran untuk materi dinamika gerak sistem katrol agar siswa lebih tertarik dan lebih mudah untuk memahami konsep dinamika gerak.

\section{METODE PENGABDIAN}

Metode pelaksanaan kegiatan pengabdian ini terdiri dari beberapa tahap: 1. Persiapan Program

Pada Tahap ini dilakukan koordinasi dengan Guru Fisika dan pihak sekolah SMA 2 Pekanbaru.

2. Persiapan Pelatihan
a. Pembuatan GUI Matlab untuk Materi Dinamika Gerak
b. Penyediaan beberapa laptop untuk kegiatan pelatihan

3. Pelatihan penggunaan GUI Matlab Materi Dinamika Gerak

Tahap ini bertujuan untuk mengembangkan keterampilan atau pendekatan dan diterapkan langsung bagi guru Fisika.

4. Evaluasi 
Di akhir kegiatan, evaluasi dilakukan untuk dapat menyimpulkan dan menilai kesesuaian kegiatan yang berlangsung terhadap rancangan awal kegiatan.

\section{HASIL DAN PEMBAHASAN}

Pelatihan penggunaan aplikasi GUI Matlab untuk materi dinamika gerak ini merupakan kegiatan Pengabdian Pada Masyarakat yang diselenggarakan oleh Program Studi Fisika Universitas muhammadiyah Riau. Pelatihan ini dilaksanakan di SMA 2 Pekanbaru.

Kegiatan dilaksanakan dengan cara tatap muka dan latihan menggunakan GUI Matlab. Tahap pertama penjelasan tentang kasus dan penjabaran rumus yang digunakan, diantaranya :

1. Bidang datar dengan lantai licin

a. arah gaya ke-x positif

b. arah gaya ke-x negatif

c. arah gaya ke-x positif dengan sudut

d. arah gaya ke-x negatif dengan sudut

2. Bidang miring dengan lantai licin

a. arah gaya ke-x positif

b. arah gaya ke- $x$ negatif

c. arah gaya ke-x positif dengan sudut

d. arah gaya ke-x negatif dengan sudut

3. Bidang datar dengan lantai kasar

a. arah gaya ke-x positif

b. arah gaya ke-x negatif

c. arah gaya ke-x positif dengan sudut

d. arah gaya ke-x negatif dengan sudut

4. Bidang miring dengan lantai kasar

a. arah gaya ke-x positif

b. arah gaya ke-x negatif

c. arah gaya ke-x positif dengan sudut

d. arah gaya ke-x negatif dengan sudut
GUI yang dirancang dapat menyelesaikan kasus-kasus diatas. Dengan GUI Matlab materi dinamika gerak ini diharapkan sebagai alternatif yang efektif bagi guru untuk meningkatkan pemahaman siswa. Perancangan yang friendly membuat siswa hanya perlu memasukkan besaran-besaran input yang dibutuhkan yaitu massa benda, nilai dan arah gaya, bidang datar atau miring. Ouput yang muncul adalah gambar bidang dengan uraian garis gaya, rumus yang digunakan dan nilai percepatan.

GUI Matlab materi dinamika gerak yang digunakan pada pelatihan ini dapat dilihat pada Gambar 1. Peserta dapat memasukkan input di bagian panel input dan menyesuaikan keadaan sistem yang diinginkan dengan mengatur radiobutton yang disediakan.

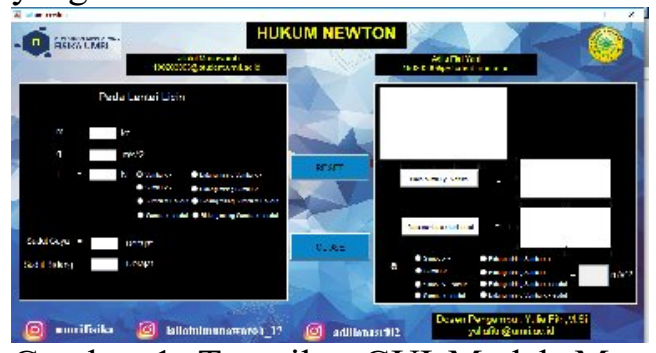

Gambar 1. Tampilan GUI Matlab Materi Dinamika gerak

Gambar 2 menunjukkan kasus 1a, yaitu bidang datar dengan lantai licin dan arah gaya ke-x positif. Dengan memasukkan input Massa benda $50 \mathrm{~kg}$, dengan gaya sebesar $2 \mathrm{~N}$ kearah sumbu $\mathrm{X}$ positif. Pada kasus ini bidang datar dan licin, maka nilai input pada sudut gaya dan sudut bidang adalah nol. Pada bagian output akan ditampilkan gambar dan uraian arah gaya, rumus yang digunakan pada sumbu $\mathrm{x}$ dan sumbu $\mathrm{y}$, dan nilai percepatan benda adalah sebesar $0,04 \mathrm{~m} / \mathrm{s}^{2}$ ke arah sumbu-x. 


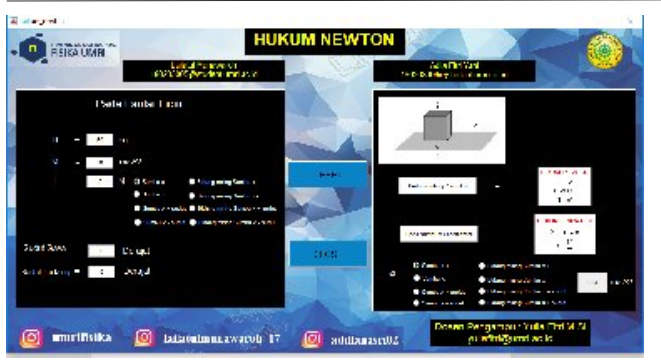

Gambar 2. Tampilan input dan output untuk kasus 1a.

Kasus selanjutnya dapat dilihat pada Gambar 3 yaitu bidang miring dengan lantai kasar. Pada kasus ini massa benda $30 \mathrm{~kg}$, gaya $10 \mathrm{~N}$ dengan membentuk sudut $30^{0}$ ke arah sumbu-x negatif, nilai koefisien gesek kinetik $\left(\mu_{\mathrm{k}}\right) \quad 0,1$ dan koefisien gesek statis $\left(\mu_{\mathrm{s}}\right)$ adalah 0,3. Sudut dari bidang miring adalah $45^{\circ}$.

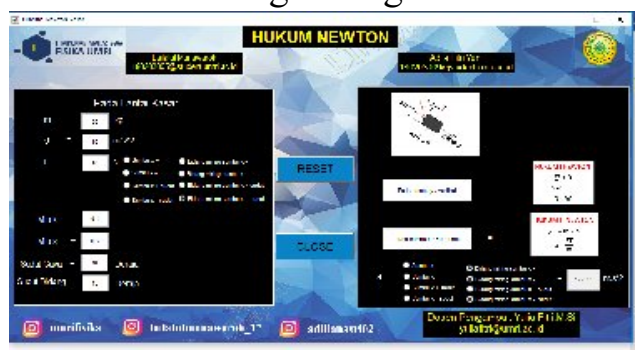

Gambar 3. Tampilan input dan output untuk kasus 4d.

Materi dilanjutkan dengan tanya jawab secara lisan. Setelah penjelasan, peserta diminta untuk berlatih menggunakan GUI Matlab dinamika gerak dengan soal-soal yang telah disiapkan.

Pada sesi penutup dilakukan evaluasi kegiatan. Dari hasil testimoni dan wawancara dengan peserta diperoleh bahwa peserta senang bisa mengikuti kegiatan pelatihan ini, lebih mudah memahami materi dinamika gerak. selain itu, kegiatan ini sangat bermanfaat karena merupakan salah satu inovasi dalam proses pembelajaran.

Kegiatan pengabdian masyarakat ini diharapkan dapat memotivasi guru dalam membuat media interaktif dan dapat diimplementasikan dalam proses pembelajaran di kelas. Penggunaan media menggunakan GUI Matlab ini diharapkan membuat proses pembelajaran menjadi menarik. sehingga dapat memotivasi siswa dalam belajar fisika.

\section{SIMPULAN}

Berdasarkan Kegiatan pengabdian kepada masyarakat yang telah dilakukan dapat diambil kesimpulan bahwa kegiatan ini bisa menjadi salah satu kegiatan yang mengembangkan keterampilan atau pendekatan bagi guru serta menciptakan alternatif media pembelajaran untuk materi dinamika gerak.

\section{UCAPAN TERIMAKASIH}

Pelaksana berterimakasih kepada Kepala Sekolah dan Guru-Guru Fisika SMA 2 Pekanbaru yang telah bersedia menyediakan waktu dan tempat untuk diadakan pengabdian ini. Kepada mahasiswa Fisika Angkatan 2018 yang menjadi tim pelaksana dan panitia pada program PKM ini.

\section{DAFTAR PUSTAKA}

[1] Sitanggang, F.F. Rancang bangun modul pembelajaran berbasis matlab dengan trainer pada mata pelajaran Dasar dan pengukuran listrik. Universitas Negeri Medan: Skripsi. 2016

[2] Nababa, J. ML. Pemanfaatan media belajar berbasis program aplikasi matlab untuk meningkatkan hasil belajar siswa menganalisis rangkaian listrik arus searah/ listrik dinamis kelas $\mathrm{x}$ teknik instalasi tenaga listrik smk negeri 1 balige tahun ajaran 2015/2016. Universitas Negeri Medan: Skripsi. 2016

[3] Hahn, Brian D. dan Valentine, Daniel T. Essential Matlab for Engineers and Scientists. Oxford: Elsevier Ltd. 2007

[4] Apriandi, D., \& Setyansah, R. K. Penerapan Media Simulasi Matlab Berbasis Interactive Conceptual untuk Meningkatan Pemahaman Konsep Mahasiswa. AKSIOMA: 
Jurnal Program Studi Pendidikan

Matematika, 6(2), 189-197. 2017

[5] Abdullah, Mikrajuddin. Fisika

Dasar I. Bandung : Institut

Teknologi. 2017 